Г.Г.СЕМКИНА (Омск, Россия)

\title{
О некоторых особенностях функционирования партитива
}

Ключевые слова: семантическая роль, партитив, инструментатив, словососчетание, распространенность, семантический тип сказуемого, структурный тип предложения, дискурсивный показатель.

The article deals with the functional characteristics of partitives: lexical and structural features of the partitive phrases, dependence on the semantics of the predicate, the structural type of the including sentence.

Партитив рассматривается либо как одна из семантических ролей либо как один из подвидов семантической роли инструментатива. Обычно он определяется как актант, отражающий в качестве участника ситуации часть тела человека [Худяков 2005:109]. Возможно и более широкое толкование партитива, при котором данная семантическая роль охватывает и случаи, когда участником ситуации оказывается часть неодушевленного предмета, например: I felt myself to blame for what had happened, and wiped her face with the corner of my peasant shirt. (Memoirs of a Geisha, 29). Такие употребления представляют интерес с точки зрения предельно высокой степени детализации ситуации и рематического выделения важного для определенного конкретного случая семантического элемента. Однако в большинстве случаев используется партитив в узком смысле, определение которого дано выше, его функциональные особенности и будут обсуждаться далее.

Партитив обычно выражается конкретными существительными, обнаруживающими при дефиниционном анализе в своем составе сему “часть тела, орган” (part of body, limb, organ). К таким существительным 
относятся hand, еyе, shoulder, head, ear, arm, leg, knuckle, fingernail, limb, palm, fingertip, palm, tongue и др. Приведем несколько примеров определений:

Eye - the organ of sight of animals, containing light-sensitive cells associated with nerve fibres, so that light entering the eye is converted to nervous impulses that reach the brain.

Hand - the prehensile part of the body at the end of the arm, consisting of a thumb, four fingers, and a palm

Finger - the inner part of the hand from the wrist to the base of the fingers

Foot - the part of the vertebrate leg below the ankle joint that is in contact with the ground during standing and walking or any of various organs of locomotion or attachment in invertebrates, including molluscs.

Вполне предсказуемо, что, в соответствии $\mathrm{c}$ реальной действительностью, подавляющее число партитивов представлены существительными со значением верхних конечностей человека (hand, fist, arm, finger), а а также со значением органа зрения (еуе).

Одной из важнейших характеристик функционирования исследуемой семантической роли является то, что партитивы практически всегда являются распространенными. Партитивное словосочетание обычно включает притяжательные местоимения или существительные в родительном падеже, а также прилагательные, обозначающие признак партитивного актанта. Отметим, что использование притяжательного местоимения с партитивом - характерная особенность английского языка и является обязательным при отсутствии других определителей. Например: Mrs. Fidget began to examine her face, not only with her eyes but with her fingertips. (Memoirs of a Geisha, 27)

When she was done speaking, she gave me a little shove with her foot, and I stepped down out of her way. (Memoirs of a Geisha, 89) 
Употребление в партитивном словосочетании одного или нескольких прилагательных преимущественно свойственно случаям, когда партитив выражен словом eyes (еуе), что совершенно естественно, поскольку в данном случае имеет место замена по функции - имеется в виду взгляд, или, конкретнее, отношение или настроение, выраженное взглядом. Поскольку глаза всегда выражают внутренне состояние человека, партитивное словосочетание в данном случае описывает именно его. (Использование нераспространенного партитива с лексемой eyes представляется бессмысленным ( *he looked at it with his eyes), так как подразумевается само собой, без особой экспликации). Приведем несколько характерных примеров:

He transfixed me with two sharp, steely eyes. (The Lost World, 28)

He looked at me with a very questioning eye, and I read hesitation in his face. (The Lost World, 254)

Прилагательные и причастия используются также в других партитивных словосочетаниях. Например:

Was it a fierce tiger of crime, which could only be taken fighting hard with flashing fang and claw, or would it prove to be some skulking jackal, dangerous only to the weak and unguarded? (Holmes, 209)

I tucked away my handkerchief with trembling hands, and we continued up the hill, not speaking a word. (Memoirs of a Geisha, 464)

Глаголы - сказуемые при партитивах представляют собой ограниченный, узкий круг лексем, взаимосвязанных с лексическим значением самих партитивов, что сближает глагольно-партитивные группы с устойчивыми словосочетаниям. В частности, глаголы-сказуемые при партитивах со значением верхних конечностей человека (hand, fist, arm, finger и др.) - это прежде всего глаголы направленного движения или действия, которые можно разграничить по семантике:

‘бить, ударять’ (beat, strike, fight, bang, crush) , например: 
Our attention was arrested by a tremendous ring at the bell, followed immediately by a hollow drumming sound, as if someone were beating on the outer door with his fist. (Holmes, 34)

"Years ago, when I was a boy," said Dorian Gray, crushing the flower in his hand, "you met me, flattered me, and taught me to be vain of my good looks." (Dorian Gray, 150)

'толкать, дергать' (pull, jerk), например:

"Yes; she is a peacock in everything but beauty," said Lord Henry, pulling the daisy to bits with his long nervous fingers. (Dorian Gray, 9)

Kazuko, the elderly maid who had shown us in, pulled my collar aside with both hands. (Memoirs of a Geisha, 249)

'стучать, звонить' (ring, drum), например:

The lad muttered something to himself and drummed on the window-pane with his coarse fingers. (Dorian Gray, 63)

The Time Traveller pushed his glass towards the Silent Man and rang it with his fingernail; at which the Silent Man, who had been staring at his face, started convulsively, and poured him wine.(The Time Machine, 20) ‘указывать, отмечать, махать, изучать, трогать' (point, mark, swing, touch, measure), например:

And he put it to us in this way--marking the points with a lean forefinger - as we sat and lazily admired his earnestness over this new paradox (as we thought it) and his fecundity.(The Time Machine, 1)

She touched the top of it with her fingers. (Farewell, 109)

Глаголы ненаправленного действия были представлены узкой лексической группой со значениями 'держать(ся), схватить, висеть' (hold, grip, hang, cling), например:

I do not think it could have made off so fast among the branches if it could not get a grip with its feet. (The Lost World, 185) 
I was lucky to have a heavy timber to hold on to, and I lay in the icy water with my chin on the wood, holding as easily as I could with both hands. (Farewell, 222).

Глаголы перцептивной деятельности со значением 'смотреть, глядеть, вглядываться, наблюдать’ (stare, look, watch, gaze, glare, see, etc.) естественным образом главенствовали в партитивных словосочетаниях с существительным еуеs, например:

He glared back at me with hard angry eyes, but I refused to give way. (The Lost World, 73)

The old man lay back in his chair, with a twitching face, and stared at her with brooding eyes. (Holmes, 347)

Еще более сближаются с устойчивым сочетаниями беспредложные глагольно-партитивные группы). Лексическую базу партитивов в таких случаях представляют слова, обозначающие подвижную часть тела (hand, shoulder, head, etc.), а лексическую базу сказуемого, от которого зависит партитив, представляют глаголы со значением 'махать, качать, размахивать' (wave, nod, toss, shake и др.), например, wave smb’s hand, shake/toss/nod sbm's head, shrug smb's shoulders:

The Indians now could only shake their heads and shrug their shoulders when we expressed by signs our desire to descend. (The Lost World, 245)

Что касается предлогов, которые используются вместе с партитивами, то

основными из них являются with, in и by. Причем, если предлог with используется практически со всеми словами, имеющими в своем составе сему 'часть тела, орган', то предлог in добавляет партитиву оттенок локативности и используется только со словами, обозначающими верхние конечности человека (hand, arm, finger). Приведем несколько примеров: 
"Years ago, when I was a boy,” said Dorian Gray, crushing the flower in his hand, "you met me, flattered me, and taught me to be vain of my good looks." (Dorian Gray, 150)

'She's been like this since she went to Albufeira with Una Alconbury and Audrey Coles,' he sobbed, trying to wipe his cheek with his fist. (Bridget Jones, 32)

Could all go out for meal but then feel guilty asking everyone to pay, selfishly down, staring crazily at the door with one eye. (Bridget Jones, 47)

Предлог bу является наименее распространенным:

Usually they were stacked in a crate that was either carried by hand or strapped to a bicycle; I don't know why this young man was using a tray. (Memoirs of a Geisha, 186)

I tried to brush it away with my hand, but in a moment it returned, and almost immediately came another by my ear. (The Time Machine, 106)

Для понимания смысла употребления партитива в высказывании важным является тот факт, что подавляющее большинство предложений, включающих этот семантический элемент, являются в высокой степени распространенными, объемными, содержащими большое количество второстепенных членов. Это преимущественно либо осложненные, либо сложные предложения. Среди осложнителей много причастных оборотов и однородных членов, например:

And therewith, taking the lamp in his hand, he led the way down the long, draughty corridor to his laboratory. (The Time Machine, 13)

I beat the ground with my hands, and got up and sat down again, and wandered here and there, and again sat down. (The Time Machine, 97). Важно, что сами партитивные словосочетания зачастую выступают а качестве осложнителей при их обособлении, например:

In his fingers, as smooth as driftwood, he held a sake cup. (Memoirs of a Geisha, 187) 
For a moment Gilchrist, with upraised hand, tried to control his writhing features. (Holmes, 313)

Сложные предложения, содержащие партитив, обладают преимущественно многоступенчатой структурой с различными видами синтаксичесих связей, например:

I was limp while she did it; she had to support my chin in her hand to keep my head from rolling. (Memoirs of a Geisha, 454)

I hoped he would reply, but he only made a gesture with his hand that meant for me to leave. (Memoirs of a Geisha, 14)

Достаточно редкие простые неосложненные предложения всегда являются распространенными, в них используется не только партитив, выступающий в качестве дополнения, но и другие распространители, в частности, другие дополнения, различные обстоятельства (цели, места, способа действия), определения:

I banged with my fist at the bronze panels.(The Time Machine, 49)

He shook his head with a half-smile at McMurdo.(Valley, 156)

Таким образом, вполне очевидным представляется то, что партитив стремится вовлечь в предложение как можно больше других, факультативных семантических ролей, чтобы более обстоятельно описать ситуацию. В дискурсивном отношении партитив характерен для подробного нарративного повествования с большим количеством деталей, зримо воспроизводящих положение дел.

Рассмотрение функциональных особенностей партитивов позволяет говорить, с одной стороны, о несомненных отличительных характеристиках, a, с другой стороны, об очевидной лексической и структурной ограниченности партитивных словосочетаний. Такое положение свидетельствует об обоснованности позиционирования партитива как одного из подтипов инструментатива, но не отдельной семантической роли в общей классификации семантических ролей 
высказывания. При этом необходимо отметить особую дискурсивную важность партитива как одного из признаков детализированного описательного нарратива.

Литература

1. Худяков А.А. Теоретическая грамматика английского языка [Текст]: учебное пособие/ А.А.Худяков. - М.: Академия, 2005. - 256c. 